\title{
Impact of Merger on HDFC Bank Financial Performance: A CAMEL Analysis Approach
}

\author{
Shweta Yadav ${ }^{1} \&$ Jonghag Jang ${ }^{2}$ \\ ${ }^{1}$ School of Economics and Management, Chang'an University, Xi'an, China \\ ${ }^{2}$ Faculty of School of Economics and Management, Chang'an University, Xi'an, China \\ Correspondence: Jonghag Jang, Faculty of School of Economics and Management, Chang'an University, South \\ $2^{\text {nd }} \mathrm{Rd}$, Xi'an, China. E-mail: yuhajang@naver.com
}

Received: May 10, 2021

Accepted: July 12, 2021

Online Published: July 18, 2021

doi:10.5539/ijef.v13n8p31

URL: https://doi.org/10.5539/ijef.v13n8p31

\begin{abstract}
The main purpose of this study is to examine the impact on financial performance of HDFC Bank before and after the merger and to compare the pre and post-merger effect caused on its financial performance by CAMEL Analysis. The data used in the study is secondary data covering total time period of ten years which include five year prior merger (2003-2008) and five year of post-merger period (2009-2014). The research technique used in this study is CAMEL Analysis. Paired sample T-test has been also conducted to check the statistical significance difference between before and after merger CAMEL ratios and to measure the effect of merger on financial performance. The result showed that the financial performance of HDFC increased after the merger and positively impacted by the act of merger.
\end{abstract}

Keywords: merger, financial performance, CAMEL analysis, T-test

\section{Introduction}

The terms "mergers" and "acquisitions" are often used interchangeably, but in reality, they carry bit different meanings. Merger takes place when two organization come together to form a new one whereas, acquisition takes place when one organization takes over another organization, and form a new entity. M\&A basically happens to expand size of the organization, to gain competitive advantage, to gain market share, to expand into new segments, etc.

Banks are financial institutions that accept savings of the public and grants loans and advances to business, industry and society at large. Banks acts as a mediator between saver and investors and also helps in better functioning of a country's economy. The Banking industry is one of the important area where M\&A make tremendous amount of financial gains.

The merger in Indian banking sector started during 1960s to rescue the weaker banks and to protect interest of customers. The period from 1961-1969 was considered as pre-nationalized period because during that time the government nationalized 14 private banks and also approve 46 mergers in order to improve the condition of poor banks that come out to be a successful move. The period after pre-nationalization is called as post nationalized period (1969-1991) in which 6 banks got nationalization and 13 private and public banks got approval for merger. The post liberalization period (1991-2015) in which new policies were framed and foreign investment was started, in addition 22 mergers happened.

HDFC Bank was formed in 1994 as a subsidiary of Housing Development Finance Corporation. The first merger that took place in the new generation private sector bank was of HDFC and Times Bank in February 2000 and the second merger was with Centurion Bank of Punjab (CBOP) in 2008 that was considered to be the largest merger in the history of financial sector in India. HDFC bank and CBOP both are Private Indian banks that provides financial services and retail and corporate banking services respectively. HDFC bank is considered to be the largest private bank in India in form of its assets.

In this paper we will assess the impact of merger on HDFC financial performance by using CAMEL analysis approach. For this study total of ten years data is taken which means five year (2003-2008) for pre-merger and five year (2009-2014) for post-merger and to check the significance difference between pre-merger and post-merger independent t-test is also used with 0.05 level of significance. 


\section{Literature Review}

Brahma (2018), made a comparative analysis between SBI and ICICI Bank using CAMEL approach. The result showed that both the banks are running profitably both with regard to profitability and management efficiency, ICICI has shown a better performance as compared to that of SBI.

Ashwin and Princika (2018), studied a comparison between SBI and ICICI to analyze their finance performance using CAMEL analysis. Their study concluded that ICICI Bank needs to improve its performance especially in terms of its capital adequacy and asset quality whereas, SBI Bank needs improvement in terms of its management efficiency, liquidity and earning quality.

Kaur and Kaur (2016), analyzed the financial performance of public sector banks during (2004-05 to 2013-14) using CAMEL analysis. The result rating showed that both BOB and PNB Bank to be most stable banks among all the banks whereas, Indian overseas Bank and IDBI Bank as average and the Bank of India, Union bank, SBI $\&$ Syndicate Bank are considered as below average.

Singh and Pawan (2016), made an analysis of five private sector banks that are HDFC, Axis bank, ICICI, Yes bank and Indusland bank to know their financial performance using CAMEL methodology. The study reveals that overall performance of HDFC bank is excellent and got $1^{\text {st }}$ Rank among its rival banks, it is also concluded that Indusland bank and Axis bank performance is good.

Panboli and Birda (2019), studied CAMEL approach on selected private and public sector banks in India. The study has undertaken five banks from both the sectors which include ICICI, HDFC, Axis bank, Yes bank, Kotak Mahindra (private banks) and SBI, PNB, BOB, UBI \& Canara Bank (public banks). The data collected was of five years and the method used was Camel Methodology to assess all bank performance. Based on the result the study concluded that HDFC and Axis bank are performing above average. Overall the result showed that performance of private sector are better than that of public sector banks.

Yusuf (2015), analyzed the impact of pre \& post-merger financial performance of Jordan Ahil bank. Financial ratios method was used to determine financial performance and paired sample t-test to determine the significance difference in the financial performance. The result shown that 5 ratios significantly improved, 3 ratios improved but in significantly, 3 ratios significantly deteriorated and 1 ratio insignificantly deteriorated after the merger. The researcher also concluded that Jordan Ahil bank insignificantly improved after the merger.

Bushra, Abdulwahab, and Ganguli (2017), measured the impact of M\&A on financial performance of kingdom of Bahrain banks from 2004 to 2015. CAMEL rating model approach and financial modelling were used to know the significant difference in the financial performance of banks of Bahrain. The result found that there was no significant improvement have been noticed in local banks of Bahrain's financial performance. Only Bahraini Saudi bank showed significant improvement in the financial performance during post-merger. Whereas, no significant change has been noticed in the overall CAMEL ratios of all the banks.

Rajamani and Ramakrishna (2015), studied the impact of merger of CBOP on HDFC bank's financial performance. The result indicated that GPM, NPM, ROCE, ROE, D/E ratio shown an increasing trend but OPM, shown mixed trend. The result also shown that there is significant difference in GPM, NPM, ROE, D/E ratio between pre-merger and post-merger.

Adnan (2014), investigated the financial performance of ERBIL Bank during 2009-2013. Financial ratios were used to determine the financial performance and statistical tool used to analyze several variables to know whether these variables are significantly correlated with financial performance of bank. The finding showed positive impact on Erbil bank's financial performance.

Sonia (2013), studied the pre and post-merger impact on the Financial Performance of different companies. The researcher considered 9 metal companies merger during 2009-10 for her studies. She used financial ratios and paired t-test to examine the pre-post period effect. The finding showed a marginal but no significant improvement in case of liquidity and leverage. Overall, the research concluded that in case of M\&A synergy can be generated with careful usage of resources in long run.

Veena and Patti (2016), the objective of the researcher was to evaluate Financial Performance of ICICI Banks. The researcher used Profitability ratio, Liquidity Ratio, Leverage and Growth Ratio to analyze Financial Performance. The result indicated that there was no significant difference found between pre and post-merger financial performance. Finally, the researcher suggested that the financial performance of ICICI LTD during post-merger was better than pre-merger. 


\section{Objective}

- To measure the effect of pre-merger and post-merger on the financial performance of HDFC Bank using CAMEL Analysis.

- To compare the pre-merger and post-merger effect on financial performance HDFC Bank.

\section{Methodology}

\subsection{Source of Data}

The data used in this study is secondary data that means that all data used is collected from annual reports of the bank and different journals.

\subsection{Period of Study}

The merger of HDFC bank with Centurion bank of Punjab held on $1^{\text {st }}$ April 2008 for the purpose of growth and making the bank bigger to join hands together. Therefore, total of ten years of data is considered in this study that means five year prior to merger (2003-2008) and five year post merger (2009-2014).

\subsection{Research Technique}

CAMEL Analysis is used to analyze the pre and post-merger financial performance of HDFC. The CAMEL methodology has been widely accepted as a tool for evaluating the financial performance of banks. CAMEL is an acronym for C- Capital Adequacy, A- Asset Quality, M- Management Efficiency, E- Earning Efficiency and L- Liquidity Position. To compare the Pre-merger and Post-merger performance and to check significant difference between them a paired sample T-test is employed.

\subsubsection{CAMEL Model}

\section{A. Capital Adequacy}

Capital Adequacy indicates financial health of a bank. It specify the capability of a bank to bear unexpected losses through their capital. It suggests the overall financial position of the banks, the ability of the management to fulfill the requirement of additional capital and also to maintain depositor's confidence and lastly to prevent the banks from bankruptcy.

> Capital Adequacy Ratio (CAR) - As per RBI rules, Indian commercial banks are required to maintain a CAR of $9 \%$ while Indian public sector banks are emphasized to maintain a CAR of $12 \%$.

$$
\text { CAR = Tier I capital }+ \text { Tier II capital } / \text { Risk Weighted Assets } * 100
$$

$>$ Advances to Total Asset Ratio - This ratio basically suggests that how many assets have been given as advances. An aggressive bank will try to earn more profits by giving out more advances.

$$
\text { Advance to Assets Ratio }(\%)=\text { Advance } / \text { Assets } * 100
$$

\section{B. Asset Quality}

The financial health and strength of any assets can be measured by looking as its quality. The poor quality leads the bank to fail. The quality of assets determine the kind of the debtors the bank is having.

$>$ Gross NPA to Gross Advances $=$ Gross NPA / Gross Advances * 100

\section{$>$ Net NPA to Net Advances $=$ Net NPA / Net Advances $* 100$}

This ratio indicates how good a bank's provisioning practices. Lower ratio indicates a good sign of credit efficiency of a bank whereas, the high ratio indicates bank's weak performance.

\section{Management Efficiency}

Management efficiency is the ability of the management to ensure the safe operation of an organization as it compose of requisite internal and external regulations. The management is also responsible for handling financial stress and to manage and control risk occur in daily activities. The ratios in this element involve subjective analysis to measure the efficiency and effectiveness of management.

Business per Employee - This ratio helps in calculating employee's efficiency in generating business for the bank. It is measured by dividing the total business by the total number of employees. Business means the sum of total advances and total deposits in a particular year.

$$
\text { Business per Employee = Total Business (Deposits }+ \text { Advances) } / \text { No. of Employees }
$$

Profit per Employee - This ratio calculates the employee's efficiency in generating profit for the banks. This ratio is measured by dividing the total profit earned by the bank, by the total number of employees. The 
higher the ratio, the higher will be the efficiency of employees.

$$
\text { Profit per Employee }=\text { Net Profits } / \text { No. of Employees }
$$

$>$ Return on Assets (ROA) - It measures the efficiency of a business in using its assets to generate net income. It gives an idea that how efficient a management is at using its assets to generate earnings.

$$
\text { Return on Asset }=\text { Net profit } / \text { Total Assets } * 100
$$

$>$ Return on Equity (ROE) - Return on equity (ROE) reveals that how much funds invested by the banker have converted into income.

$$
\text { Return on Equity }(\text { ROE })=\text { Net Income } / \text { Shareholder's Wealth } * 100
$$

D. Earning Efficiency

The earning efficiency refers to the capability of a bank to earn consistently, going into the future. This parameter explains the sustainability and growth in earnings in future and how a bank earns its profits. By increasing capacity of earning, banks can increase their growth and productivity.

$>$ Operating Profit to Total Assets- This ratio indicates how much operating profits are generated through utilizing assets of the bank.

$$
\text { Operating Profits to Total Assets }=\text { EBIT } / \text { Total Assets } * 100
$$

$>\quad$ Net Profit to Total Assets - This ratio indicates how much profit is left after paying off interest and taxes. Again it is calculated against total assets.

$$
\text { Net Profits to Total Assets = Earning after interest and taxes } / \text { Total Assets *100 }
$$

E. Liquidity Position

Risk of liquidity is curse to the image of bank. Bank has to take proper care to hedge the liquidity risk; at the same time ensuring good percentage of funds are invested in high return generating securities, so that it is in a position to generate profit with provision liquidity to the depositors. Among assets cash and investments are the most liquid of a bank assets. Liquidity can neither be very low nor be very high because very low liquidity means that banks are not capable to meet its current financial liabilities and on the other hand very high liquidity means that banks are not utilizing their cash in proper manner. So it's important for the banks to make a proper balance in case of liquidity so that banks can generate high profit while at the same time provide liquidity to the depositors.

$>$ Liquidity Assets to Total Assets - The proportion of liquid assets to total assets indicates the overall liquidity position of the bank. Liquid assets include cash in hand, balance with the RBI, balance with other banks (both in India an abroad) and money at call and short notice.

$$
\text { Liquid Assets to Total Assets = Liquid Assets / Total Assets *100 }
$$

$>$ Liquid Assets to Total deposits - This ratio measures the liquidity available to the deposits of a bank. Total deposits include demand deposits, saving deposits, term deposits and deposits of other financial institutions. Liquid assets includes cash in hand, balance with RBI, balance with other banks, and money at calls and short notice.

$$
\text { Liquid Assets to Total Deposits = Liquid Assets } / \text { Total Deposits } * 10
$$

\subsubsection{Hypothesis Testing}

> T-test: A paired sample for means (2 tailed) at $95 \%$ significance level $(0.05)$ has been used to test the hypothesis. MS-Excel is used to in this study.

\section{$>$ Hypothesis Statements}

Hypothesis $1=$ There is significant difference between pre and post-merger Capital adequacy ratio of HDFC Bank.

Hypothesis $2=$ There is significant difference between pre and post-merger Asset quality ratio of HDFC Bank.

Hypothesis $3=$ There is significant difference between pre and post-merger Management Efficiency ratio of HDFC Bank.

Hypothesis $4=$ There is significant difference between pre and post-merger Earning Quality of HDFC Bank.

Hypothesis $5=$ There is significant difference between pre and post-merger Liquidity Position of HDFC Bank.

Hypothesis $6=$ There is significant difference between pre and post-merger Financial performance of HDFC Bank. 


\section{Data Analysis and Interpretation}

\section{$>$ Capital Adequacy}

Table 1a. Pre \& Post merger capital adequacy of HDFC bank from 2003-2014

\begin{tabular}{ccccccccccc}
\hline & \multicolumn{4}{c}{ PRE-MERGER } & \multicolumn{4}{c}{ POST-MERGER } \\
\cline { 2 - 13 } RATIOS & $\mathbf{2 0 0 3 - 0 4}$ & $\mathbf{2 0 0 4 - 0 5}$ & $\mathbf{2 0 0 5 - 0 6}$ & $\mathbf{2 0 0 6 - 0 7}$ & $\mathbf{2 0 0 7 - 0 8}$ & $\mathbf{2 0 0 9 - 1 0}$ & $\mathbf{2 0 1 0 - 1 1}$ & $\mathbf{2 0 1 1 - 1 2}$ & $\mathbf{2 0 1 2 - 1 3}$ & $\mathbf{2 0 1 3 - 1 4}$ \\
\hline Capital Adequacy & 11.66 & 12.16 & 11.41 & 13.08 & 13.6 & 17.4 & 16.2 & 16.5 & 16.8 & 16.1 \\
Advances to total asset & 41.94 & 49.71 & 47.69 & 51.45 & 47.62 & 56.56 & 57.68 & 57.83 & 59.88 & 61.63 \\
\hline
\end{tabular}

Source: Data collected from annual report of HDFC bank.

Table 1b. T-test Paired two sample for means

\begin{tabular}{cccccccc}
\hline Ratios & Merger & Mean & Standard Deviation & DF & T-value & P-value & Hypothesis \\
\hline Capital & Pre & 12.38 & 0.87 & 4 & -7.51 & 0.001 & Accepted \\
\cline { 2 - 6 } Adequacy & Post & 16.6 & 0.27 & & & & Accepted \\
\hline $\begin{array}{c}\text { Advances to } \\
\text { total asset }\end{array}$ & Pre & 47.68 & 12.82 & 4 & -7.93 & 0.001 & \\
\cline { 2 - 5 } & Post & 58.71 & 4.08 & & & & \\
\hline
\end{tabular}

Source: On the basis of researcher's own calculations.

Table $1 \mathrm{~b}$ indicates that the Capital Adequacy Ratio during pre-merger is 12.38 which increased in post-merger to 16.6. Which means that Capital Adequacy ratio seen an increase after the merger and also the ratio from the year 2003-2014 is considered to be satisfactory and above the standard fixed by the Reserve Bank of India for Indian banks. Hence, we can say that HDFC was able to manage the requirement of minimum CAR. It also shows that HDFC is adequately capitalized before and after the merger. Similarly on the other hand Advances to total asset ratio also increased from 47.68 to 58.71 after the merger. Which means that more advances has been given out of its total assets by HDFC after the merger as compared to pre-merger.

The independent t-test reveals that both capital adequacy and asset quality ratio has T-value -7.51 and -7.93 respectively whereas, P-value is 0.001 which is less than 0.05 level of significance so, null hypothesis is accepted for both the ratios, this clearly shows that there is significant difference between pre and post-merger of capital adequacy and asset quality ratio. Hence, capital adequacy and asset quality increased after the merger and it is statistically significant.

\section{Asset Quality}

Table 2a. Pre \& Post merger asset quality of HDFC bank

\begin{tabular}{|c|c|c|c|c|c|c|c|c|c|c|}
\hline \multirow[b]{2}{*}{ RATIOS } & \multicolumn{5}{|c|}{ PRE-MERGER } & \multicolumn{5}{|c|}{ POST-MERGER } \\
\hline & 2003-04 & 2004-05 & 2005-06 & 2006-07 & 2007-08 & 2009-10 & 2010-11 & 2011-12 & 2012-13 & 2013-14 \\
\hline Gross NPA to gross advances & 1.85 & 1.69 & 1.32 & 1.32 & 1.34 & 1.43 & 1.05 & 1.02 & 0.97 & 0.98 \\
\hline Net NPA to net advances & 0.16 & 0.24 & 0.44 & 0.43 & 0.47 & 0.31 & 0.19 & 0.18 & 0.2 & 0.27 \\
\hline
\end{tabular}

Source: Data collected from annual report of HDFC bank.

Table 2b. T-test Paired two sample for means

\begin{tabular}{|c|c|c|c|c|c|c|c|}
\hline Ratios & Merger & Mean & Standard Deviation & DF & T-value & P-value & Hypothesis \\
\hline \multirow[t]{2}{*}{ Gross NPA to gross advances } & Pre & 1.504 & 0.06223 & \multirow[t]{2}{*}{4} & \multirow[t]{2}{*}{6.94} & \multirow[t]{2}{*}{0.002} & \multirow[t]{2}{*}{ Accepted } \\
\hline & Post & 1.09 & 0.03715 & & & & \\
\hline \multirow[t]{2}{*}{ Net NPA to net advances } & Pre & 0.348 & 0.01927 & \multirow[t]{2}{*}{4} & \multirow[t]{2}{*}{1.55} & \multirow[t]{2}{*}{0.19} & \multirow[t]{2}{*}{ Rejected } \\
\hline & Post & 0.23 & 0.00325 & & & & \\
\hline
\end{tabular}

Source: On the basis of researcher's own calculations.

Table $2 b$ indicates that mean value of both asset quality ratios fell down in post-merger period. The pre-merger mean value of Gross NPA to gross advances and Net NPA to net advances are 1.504 and 0.348 respectively which fell down to 1.09 and 0.23 respectively in post-merger period. This depicts that HDFC non-performing assets decreases which leads to decrease in asset quality of HDFC after the merger. 
The t-test reveals that $t$-value of Gross NPA to gross advances is 6.94 and p-value is 0.002 which is less than 0.05 level of significance and null hypothesis is accepted whereas, t-value of Net NPA to net advances is 1.55 and p-value is 0.19 which is more than 0.05 level of significance so null hypothesis is rejected and alternative hypothesis is accepted. This clearly states that Gross NPA to gross advances shown a significant decrease and Net NPA to net advances sown an insignificant decrease after the merger.

\section{$>$ Management Efficiency}

Table 3a. Pre \& Post merger management efficiency of HDFC bank

\begin{tabular}{ccccccccccc}
\hline & \multicolumn{4}{c}{ PRE-MERGER } & \multicolumn{4}{c}{ POST-MERGER } \\
\cline { 2 - 12 } RATIOS & $\mathbf{2 0 0 3 - 0 4}$ & $\mathbf{2 0 0 4 - 0 5}$ & $\mathbf{2 0 0 5 - 0 6}$ & $\mathbf{2 0 0 6 - 0 7}$ & $\mathbf{2 0 0 7 - 0 8}$ & $\mathbf{2 0 0 9 - 1 0}$ & $\mathbf{2 0 1 0 - 1 1}$ & $\mathbf{2 0 1 1 - 1 2}$ & $\mathbf{2 0 1 2 - 1 3}$ & $\mathbf{2 0 1 3 - 1 4}$ \\
\hline Business per employee & 6.12 & 6.06 & 7.02 & 6.07 & 5.06 & 6.98 & 7.53 & 7.54 & 8.59 & 8.99 \\
\hline Profit per employee & 7.39 & 8.8 & 7.39 & 6.13 & 4.97 & 5.98 & 7.37 & 8.12 & 7.12 & 8.12 \\
\hline Return on asset & 1.45 & 1.47 & 1.38 & 1.33 & 1.32 & 1.53 & 1.58 & 1.77 & 1.9 & 2 \\
\hline Return on equity & 18.92 & 14.72 & 16.43 & 17.74 & 13.83 & 13.7 & 15.47 & 17.26 & 18.57 & 19.5 \\
\hline
\end{tabular}

Source: Data collected from annual report of HDFC bank.

Table 3b. T-test Paired two sample for means

\begin{tabular}{|c|c|c|c|c|c|c|c|}
\hline Ratios & Merger & Mean & Standard Deviation & DF & T-value & P-value & Hypothesis \\
\hline \multirow[t]{2}{*}{ Business per employee } & Pre & 6.066 & 0.48128 & 4 & -3.003 & 0.03 & Accepted \\
\hline & Post & 7.926 & 0.69343 & & & & \\
\hline \multirow[t]{2}{*}{ Profit per employee } & Pre & 6.936 & 2.10038 & 4 & -0.47 & 0.65 & Rejected \\
\hline & Post & 7.342 & 0.77892 & & & & \\
\hline \multirow{2}{*}{ Return on asset } & Pre & 1.39 & 0.00465 & 4 & -3.04 & 0.03 & Accepted \\
\hline & Post & 1.756 & 0.04063 & & & & \\
\hline \multirow[t]{2}{*}{ Return on equity } & Pre & 16.328 & 4.38707 & 4 & -0.33 & 0.75 & Rejected \\
\hline & Post & 16.9 & 5.49085 & & & & \\
\hline
\end{tabular}

Source: On the basis of researcher's own calculations.

Table $3 b$ indicates that mean value of all the ratios of management efficiency increases after the merger. The mean value of Business per employee and profit per employee increases from 0.48128 and 2.10038 respectively to 0.69343 and 0.77892 . Which means that efficiency of all the employees of HDFC in generating productivity for their bank increases and similarly their contribution in generating more profit also increases after the merger. The mean value of ROA during pre-merger is 1.39 which increases in post-merger to 1.756 similarly, the mean value of ROE increases from 16.328 (pre-merger) to 16.9 (post-merger). Which clearly depicts that efficiency of HDFC in using its assets to generate income increases and also their capabilities in generating return on the investments it received from shareholder after the merger.

The independent $t$-test reveals that the $t$-value of Business per employee is -3.003 and p-value is 0.03 which is less than 0.05 level of significance so the null hypothesis is accepted as it shows a significant increase after the merger whereas, Profit per employee shows an insignificant increases after the merger because the p-value is 0.65 which is more than 0.05 so alternative hypothesis is accepted in this case. The ROA t-value is -3.04 and p-value is 0.03 which is less than 0.05 so the null hypothesis is accepted as it shown an significant increase after the merger whereas, t-value of ROE is -0.33 and p-value is 0.75 which is more than 0.05 level of significance and null hypothesis is rejected and alternative hypothesis is accepted as ROE shown an insignificant increase after the merger.

\section{$>$ Earning Management}

Table4a. Pre \& Post merger earning management of HDFC bank

\begin{tabular}{ccccccccccc}
\hline & \multicolumn{4}{c}{ PRE-MERGER } & \multicolumn{4}{c}{ POST-MERGER } \\
\cline { 2 - 12 } RATIOS & $\mathbf{2 0 0 3 - 0 4}$ & $\mathbf{2 0 0 4 - 0 5}$ & $\mathbf{2 0 0 5 - 0 6}$ & $\mathbf{2 0 0 6 - 0 7}$ & $\mathbf{2 0 0 7 - 0 8}$ & $\mathbf{2 0 0 9 - 1 0}$ & $\mathbf{2 0 1 0 - 1 1}$ & $\mathbf{2 0 1 1 - 1 2}$ & $\mathbf{2 0 1 2 - 1 3}$ & $\mathbf{2 0 1 3 - 1 4}$ \\
\hline Operating profit to total asset & 1.69 & 1.9 & 1.7 & 1.79 & 1.71 & 1.92 & 2.09 & 2.22 & 2.43 & 2.59 \\
\hline Net profit to total asset & 1.2 & 1.29 & 1.18 & 1.25 & 1.19 & 1.32 & 1.41 & 1.52 & 1.68 & 1.72 \\
\hline
\end{tabular}

Source: Data collected from annual report of HDFC bank. 
Table 4b. T-test Paired two sample for means

\begin{tabular}{cccccccc}
\hline Ratios & Merger & Mean & Standard Deviation & DF & T-value & P-value & Hypothesis \\
\hline \multirow{2}{*}{$\begin{array}{c}\text { Operating profit to } \\
\text { total asset }\end{array}$} & Pre & 1.758 & 0.00787 & 4 & -3.81 & 0.01 & Accepted \\
\cline { 2 - 6 } $\begin{array}{c}\text { Net profit to total } \\
\text { asset }\end{array}$ & Post & 2.25 & 0.07085 & & & & \\
\cline { 2 - 6 } & Pre & 1.222 & 0.00217 & 4 & -3.73 & 0.02 & Accepted \\
\hline
\end{tabular}

Source: On the basis of researcher's own calculations.

Table $4 \mathrm{~b}$ indicates that the pre-value mean value of Operating profit to total asset is 1.758 which increases to 2.25 after the merger similarly the mean value of Net profit to total asset increases after the merger from 1.222 to 2.225. Which means that earning efficiency of HDFC increases after the merger.

The T-test reveals that Operating profit to total asset and Net profit to total asset ratio t-value are -3.81 and -3.73 respectively and p-value are 0.01 and 0.02 respectively so in both the cases the null hypothesis is accepted as both the ratio shown a significant increase after the merger as compared to pre-merger period.

\section{$>$ Liquidity Position}

Table 5a. Pre \& Post merger liquidity of HDFC bank

\begin{tabular}{|c|c|c|c|c|c|c|c|c|c|c|}
\hline \multirow[b]{2}{*}{ RATIOS } & \multicolumn{5}{|c|}{ PRE-MERGER } & \multicolumn{5}{|c|}{ POST-MERGER } \\
\hline & 2003-04 & 2004-05 & $2005-06$ & 2006-07 & 2007-08 & 2009-10 & $2010-11$ & 2011-12 & $2012-13$ & 2013-14 \\
\hline Liquidity assets to total assets & 8.64 & 8.69 & 9.41 & 9.91 & 10.09 & 13.45 & 10.69 & 11.19 & 12.81 & 13.05 \\
\hline Liquid assets to total deposits & 10.02 & 12.3 & 10.4 & 12.24 & 14.66 & 17.88 & 14.22 & 15.48 & 14.89 & 16.77 \\
\hline
\end{tabular}

Source: Data collected from annual report of HDFC bank.

Table 5b. T-test Paired two sample for means

\begin{tabular}{|c|c|c|c|c|c|c|c|}
\hline Ratios & Merger & Mean & Standard Deviation & DF & T-value & P-value & Hypothesis \\
\hline \multirow[t]{2}{*}{ Liquidity assets to total assets } & Pre & 9.348 & 0.45112 & 4 & -5.40 & 0.005 & Accepted \\
\hline & Post & 12.238 & 1.48752 & & & & \\
\hline \multirow[t]{2}{*}{ Liquid assets to total deposits } & Pre & 11.924 & 3.41868 & 4 & -3.4577 & 0.02 & Accepted \\
\hline & Post & 15.848 & 2.17067 & & & & \\
\hline
\end{tabular}

Source: On the basis of researcher's own calculations.

Table $5 \mathrm{~b}$ indicate Liquidity ratio of HDFC Bank. The pre-merger mean value of Liquidity assets to total assets is 9.348 which jumped to 12.238 after the merger. Similarly the Liquidity asset to total deposits mean value is 11.924 which increases to 15.848 post-merger period. Which means that liquidity position of HDFC increases after the merger and also shown an increase in the efficiency of HDFC to provide sufficient liquidity to its depositors.

The t-test reveals that the t-value of Liquidity assets to total assets is -5.40 and p-value is 0.005 which is less than 0.05 so the null hypothesis is accepted as it shown a significant increases after the merger similarly the Liquidity assets to total deposits ratio shown a significant increase after the merger as compared to pre-merger because p-value value is more than 0.05 i.e., 0.02 with $\mathrm{t}$-value -3.4577 so the null hypothesis is accepted in this case also.

Table 6. Overall analysis of CAMEL ratios and its Independent t-test analysis and interpretation

\begin{tabular}{|c|c|c|c|c|c|}
\hline RATIOS & Merger & Mean & Standard deviation & P-value & Hypothesis \\
\hline \multirow[t]{2}{*}{$\mathrm{C}$} & Pre & 60.064 & 16.81393 & 0.000 & Accepted \\
\hline & Post & 75.316 & 3.14023 & & \\
\hline \multirow[t]{2}{*}{ A } & Pre & 1.852 & 0.01292 & 0.001 & Accepted \\
\hline & Post & 1.32 & 0.05615 & & \\
\hline \multirow[t]{2}{*}{ M } & Pre & 30.72 & 10.8347 & 0.36 & Rejected \\
\hline & Post & 33.924 & 33.924 & & \\
\hline \multirow[t]{2}{*}{$\mathrm{E}$} & Pre & 2.98 & 0.01805 & 0.01 & Accepted \\
\hline & Post & 3.78 & 0.19035 & & \\
\hline \multirow[t]{2}{*}{$\mathrm{L}$} & Pre & 21.272 & 4.28072 & 0.01 & Accepted \\
\hline & Post & 28.086 & 47.90222 & & \\
\hline \multirow[t]{2}{*}{ Total of pre $\&$ post-merger and their t-test analysis } & Pre & 116.888 & 18.83497 & 0.001 & Accepted \\
\hline & Post & 142.426 & 41.30888 & & \\
\hline
\end{tabular}


Source: On the basis of researcher's own calculations.

Overall Interpretation and Findings: Above table depicts all the components of CAMEL ratios, independent $\mathrm{t}$-test analysis which involve pre-merger and post-merger mean value, standard deviation, T-value and P-value. Out of five component only one component of CAMEL that is Asset quality ratio (A) shows a decline after the merger and rest of the ratios that are Capital adequacy (C), Management efficiency (M), Earning quality (E) and Liquidity position (P) all shows an increase after the merger. The null hypothesis is accepted for all the four components ratios for having $\mathrm{P}$-value less than 0.05 which are $\mathrm{C}, \mathrm{A}, \mathrm{E} \& \mathrm{~L}$ and rejected for $\mathrm{M}$ for having $\mathrm{P}$-value greater than 0.05. Capital Adequacy, Earning Quality and liquidity shows a significant increase in the value after the merger whereas, asset quality shows a significant decline after the merger and lastly Management efficiency shows an insignificant increase in the value after the merger.

Overall the mean value of post-merger is greater than the mean value of pre-merger and it shows a significant increase in the overall financial performance of post-merger as the p-value is less than 0.05 so the hypothesis is accepted and we can say that the HDFC Bank financial performance found to be positively impacted by their merger with CBOP.

\section{Conclusion}

The main aim of conducting this study is to know the actual impact caused on financial performance HDFC bank after its merger with Centurion bank of Punjab because this merger was considered to be the biggest merger in Indian banking sector in private banks and also to know that are merger really beneficially or not. For achieving our objective we used CAMEL analysis approach to access the impact of pre-merger and post-merger on financial performance and to make comparison to drive a conclusion, paired sample t-test for mean was also conducted to know the significance difference between pre-merger and post-merger performance. 0.05 was taken as the level of significance to check the difference between pre and post-merger. The final result showed that a significant increase was seen in Capital adequacy, earning management and liquidity position and a significant decrease was seen in asset quality whereas, an insignificant increase was seen in management efficiency but overall there was a significant increase in the post-merger performance. The post-merger mean value was higher than the pre-merger value. Our results are agreeing with DEVARAJAPPA S. and Bhanwar singh \& Pawan who also concluded that merger impacted the bank in positive manner. Finally, we can say that the merger between HDFC and CBOP bank has seen an increase in the financial performance after the merger and found to be positively impacted by the event of merger.

\section{Recommendation}

The Indian banking sector is the backbone of Indian financial system, playing a very important role in economic development of the country and also going by remarkable phase since last two decade witnessing high NPA, lower profitability etc. So, it is becoming very essential to go for merger for wider geographical coverage and maximizing financial stability of banks Merger is highly useful tool for growth and expansion in banks. The mergers that happens especially in banking industry are a kind of horizontal merger because it involve same kind of activities between merging entities. The benefit of M\&A in banking sector is that they can achieve significant growth, eliminate competition and minimize expenses to an extent. This study is only focus to one merger and one aspect that is financial performance. To know more about the impact of merger you can study other aspect like operating performance, profitability analysis or shareholder's wealth on the same bank or on different banks.

\section{References}

Adam, M. M. H. (2014). Evaluating the Financial Performance of Banks Using Financial Ratios- A Case Study of Erbil Bank for Investment and Finance. European Journal of Accounting Auditing and Finance Research, 2(6), 162-177.

Brahma, C. (2018). A Comparative Analysis of SBI and ICICI: Camel Approach. International Journal of Research in Management, Economics and Commerce (IJRMEC), 8(1), 151-156.

Bushra, A., \& Abdulwahab, S. G. (2017). The Impact of Mergers and Acquisitions on Financial Performance of Banks in the Kingdom of Bahrain during 2004-15. Information Management and Business Review, 9(4), 34-45. https://doi.org/10.22610/imbr.v9i4.1897

Devarajappa, S. (2012). Mergers in Indian banks: A study on mergers of HDFC bank ltd and centurion bank of Punjab ltd. International Journal of Marketing, Financial Services \& Management Research, 1(9).

Kaur, J., \& Kaur, H. (2016). Camel analysis of selected public sector banks. Gian Jyoti E-Journal, 6(3). https://doi.org/10.35291/2454-9150.2020.0287 
Panboli, S., \& Birda, K. (2019). Camel Research of Selected Private and Public Sector Banks in India. International Journal of Innovative Technology and Exploring Engineering (IJITEE), 8(12). https://doi.org/10.35940/ijitee.L3979.1081219

Purohit, A., \& Bothra, P. (2018). A Camel Model Analysis of Selected Public and Private Sector Banks in India. Proceedings of ASAR International Conference, Goa, India.

Rajamani, M., \& Ramakrishnan, P. R. (2015). A Study on Impact of Merger of Centurian Bank of Punjab on the Financial Performance of HDFC Bank. IOSR Journal of Humanities and Social Science, 20(5), 28-31. https://doi.org/10.9790/0837-20562831

Singh, B., \& Pawan. (2016). An analysis of Indian private sector banks using camel approach. International Journal of Marketing \& Financial Management, 4(7), 36-52.

Sonia. (2013). Measuring Post merger performance - A metal industry. International Journal of Applied Research and Studies, 2(8).

Veena \& Patti. (2016). Financial performance analysis of pre and post-merger in banking sector: A study with reference to ICICI bank ltd. International Journal of Management (IJM), 7(7), 240-249.

Yusuf, A. K. Al-Hroot. (2015). Pre and Post-Merger Impact on Financial Performance: A Case Study of Jordan Ahli bank. European Journal of Business and Management, 7(36).

\section{Copyrights}

Copyright for this article is retained by the author(s), with first publication rights granted to the journal.

This is an open-access article distributed under the terms and conditions of the Creative Commons Attribution license (http://creativecommons.org/licenses/by/4.0/). 